\title{
Toxicology Studies on Lewisite and Sulfur Mustard Agents: \\ Genetic Toxicity of Sulfur Mustard (HD) in Chinese Hamster Ovary Cells
}

\section{Final Report}

\author{
R. F. Jostes, Jr., L. B. Sasser, and R. J. Rausch \\ Pacific Northwest Laboratory \\ P.O. Box 999 \\ Richland, WA 99352
}

May 1989

Supported by

U.S. Army Medical Research and Development Command

Fort Detrick, Frederick, MD 21701-5012

Army Project Order No. 84PP4865

Contracting Officer's Representative:

Jack C. Dacre, Ph.D., D.Sc. Health Effects Research Division

U.S. Army Biomedical Research Division Laboratory

Fort Detrick, Frederick, MD 21701-5010

Approved for public release; distribution unlimited

The findings in this report are not to be construed as an official Department of the Army position unless so designated by other authorized documents. 


\title{
DISCLAIMER
}

This report was prepared as an account of work sponsored by an agency of the United States Government. Neither the United States Government nor any agency thereof, nor Battelle Memorial Institute, nor any or their employees, makes any warranty, expressed or implied, or assumes any legal liability or responsibility for the accuracy, completeness, or usefulness of any information, apparatus, product, or process disclosed, or represents that its use would not infringe privately owned rights. Reference herein to any specific commercial product, process, or service by trade name, trademark, manufacturer, or otherwise does not necessarily constitute or imply its endorsement, recommendation, or favoring by the United States Covernment or any agency thereof, or Battelle Memorial Institute. The views and opinions of authors expressed herein do not necessarily state or reflect those of the United States Government or any agency thereof.

\author{
PACIFIC NORTHWEST LABORATORY \\ operated by \\ BATTELLE MEMORIAL INSTITUTE \\ for the \\ UNITED STATES DEPARTMENT OF ENERGY \\ under Contract DE-ACO6-76RLO 1830
}


REPORT DOCUMENTATION PAGE

\begin{tabular}{|c|c|c|c|c|c|}
\hline \multicolumn{2}{|l|}{$\begin{array}{l}\text { Ta REPORT SECUATY CLASSIFICATION } \\
\text { Unclassifted }\end{array}$} & \multicolumn{4}{|c|}{ 16. TESTRICTVE MARKINGS } \\
\hline \multicolumn{2}{|l|}{ 2a. SECUAITY GLASSHFICATION ALTHORITY } & \multirow{2}{*}{\multicolumn{4}{|c|}{$\begin{array}{l}\text { DISTRIBUTON / AVALABLITY OF REPORT } \\
\text { Approved for public release; distribution } \\
\text { unlimited }\end{array}$}} \\
\hline \multicolumn{2}{|l|}{$\begin{array}{l}\text { 20. OECLASSFICATION IOOWHGPADING SCHEDULE } \\
\text {... }\end{array}$} & & & & \\
\hline \multicolumn{2}{|c|}{$\begin{array}{l}\text { 4. PERFORMING ORGANZATION REPORT NUMGERIST } \\
\text { PNL }-6922\end{array}$} & \multicolumn{4}{|c|}{$\begin{array}{l}\text { 5. MONIORING ORGANIZATON REPORT NUMBÉR(S) } \\
\text {... }\end{array}$} \\
\hline $\begin{array}{l}\text { 6a. NAME OF PEAFOKMING ORGANIzATHON } \\
\text { Pecific Northwest Laboratory }\end{array}$ & 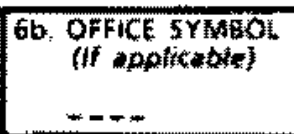 & \multicolumn{4}{|c|}{ 7. NAME OF MONITORING ORGANIZATION } \\
\hline \multicolumn{2}{|l|}{$\begin{array}{l}\text { P.o. Box } 999 \\
\text { Richland, Wh } 99352-0999\end{array}$} & \multicolumn{4}{|c|}{ 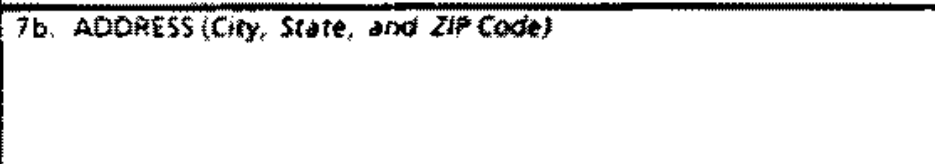 } \\
\hline $\begin{array}{l}\text { 9. NAME OF FUNOING/SPONSORING } \\
\text { OAGANZATION } \\
\text { U.5. Arny Medical Rad Command }\end{array}$ & $\begin{array}{l}\text { 8D. OFFICE SYMBOL } \\
\text { of applitablet } \\
-+-\end{array}$ & \multicolumn{4}{|c|}{ 7. PROCUREMENT INSTRUMENT DDENTIFICATION NUMBER } \\
\hline \multirow{2}{*}{\multicolumn{2}{|c|}{$\begin{array}{l}\text { Q6. ADORESS (City, state and afP Code) } \\
\text { Fort betrick }\end{array}$}} & \multicolumn{4}{|c|}{ 10. SOURCE OF FUNOING NULMEERS } \\
\hline & & $\begin{array}{c}\text { PROGRAMA } \\
\text { ELEMENT NO. } \\
53751 \mathrm{~A}\end{array}$ & $\begin{array}{l}\text { PRO IECT } \\
\text { NO } 3 \text { FI2 } \\
637510993\end{array}$ & $\begin{array}{l}\text { TaSk } \\
\text { No. } \\
\text { Co }\end{array}$ & $\begin{array}{l}\text { WOAK UAT } \\
\text { ACCESSIOA NO } \\
003\end{array}$ \\
\hline
\end{tabular}

11. TiTLE (indude Security Caswifiction)

Toxicology Studies on Lewisite and sulfur mustard Agents:

T2. PERSONAL AUTHOR(S)

R. F. Jostes. Ir., R. J. Rausch and L. B. Sasser

\begin{tabular}{|c|c|c|c|}
\hline $\begin{array}{l}\text { a. TrPE OF } \\
\text { Fine? }\end{array}$ & $\begin{array}{l}\text { 130. TIME Covero } \\
\text { FROM } \$ / 18 / 84 \text { TO } 5 / 31 / 89\end{array}$ & $\begin{array}{c}\text { 4. OATE OF REPORT (Yed, MOnth Day) } \\
1989 \text { May } 37\end{array}$ & $\begin{array}{c}\text { 15. PAGE COUN } \\
35\end{array}$ \\
\hline
\end{tabular}

16. SLPPLEMMENTARY NOTATION

Subttule: Genetic Toxicity of Sulfur Mustard (HD) in Chinese Hanster ovary Cells

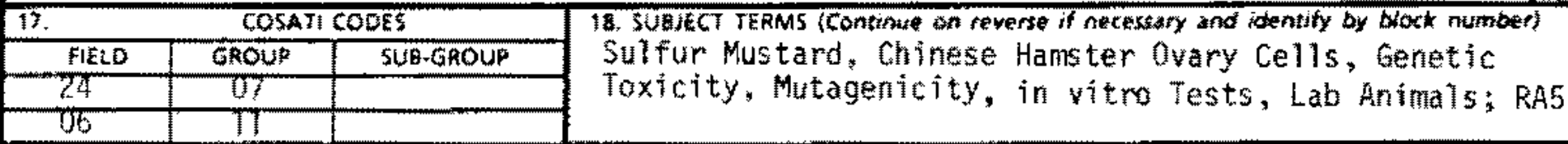

19. AaSTRkCT (Continue on reverse if necessany and identily by block mumber)

The cytotoxic, clastogenic and mutagenic effects of sulfur mustard in chinese hamster ovary cells are described in this meport. The cytotoxicity data indicate that nicromolar anounts of HD are highly toxic in micronolar amounts. Chromosone aberration frequencies increased in a dose-dependent manmer over a dose range of 0.5 to 1.0 un and 5 ct increased in a dosedependent athion in the dose range of 0.0625 to $0.25 \mu \mathrm{M}$. Mutation induction at the HGPRT locus was sporadic, but the majority of the exposures resulted in mutation frequencies which were 1.2 to 4.3 fold higher than the spontaneous frequencies.
20. BISTRZBUTION IAVALABIITY OF ABSTRACT
21 ABSTRACF JECURITY CLASHALCATION

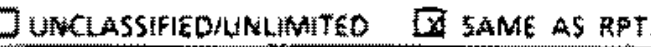

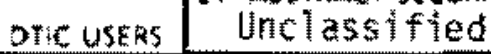

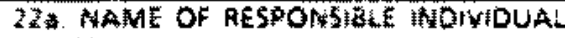

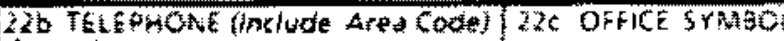

Mary Frances bostian

(30) $663-7325$

SGRL-RMII-S 


\section{FOREWORO}

Opinions, interpretations, conclusions and recomendations are those of the author and are not necessarily endorsed by the U.S. Amy.

Where copyrighted material is quoted, permission has been obtained to use such material.

Where naterial from documents designated for limited distribution is quoted, permission has been obtained to use the inaterial.

HCitations of commercial organizations and trade names in this report do not constitute an official Department of the Anmy endorsenent or approval of the products or services of these organizations.

In conducting research using animals, the investigator(s) adhered to the "Guide for the Care and use of Laboratory Animals, "t prepared by the Comnittee on Care and Use of Laboratory Animals of the Institute of Laboratory Anima] Resources, National Research Council (NIH Publication No. 86-23, Revised 1985).

For the protection of human subjects, the Investigator(s) have adhered to policies of applicable Federal law 45CFR46.

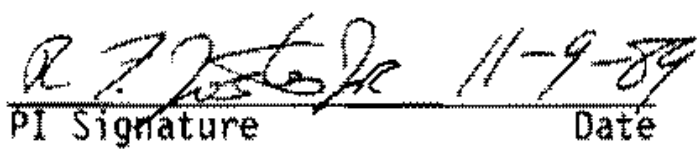





\section{EXECUTIVE SLMMARY}

Chemical warfare agents present an obvious risk to individuals suffering acute exposure, but they may also present long-term environmental or occupational health hazards for workers in operations involving these chemical agents. Dccupational health standards have not been established for sulfur mustard (HD) [bis-(2-chloroethy)-sulfide] a strong alkylating agent with known mutagenic and suspected carcinogenic properties. Sulfur mustard is used in a number of research laboratories, stored in depot sites throughout the country and occasionally transported to distant sites. The destruction of current stockpiles of sulfur mustard by the U.S. Army in the near future could create additional environmental and occupational risk. To establish a database for setting environmental and occupational standards, we have conducted studies to evaluate the toxicity, mutagenicity, and reproductive effects of sulfur mustard using in vitro and in vivo study systems.

The cytotoxic, clastogenic and mutagenic effects of sulfur mustard in Chinese hanster ovary cells were investigated and are described in this report. One mutation assay and two cytogenetic assays were used in this study. The mutation assay utilized the hypoxanthine-guanine phyosphoribosyl transferase (HGPRT) locus (6-thioguanine resistance). The two cytogenetic analyses were chromosomal aberration analysis, measurement of chromosome damage, and sister chromatid exchange (SCE), a measurement of chromosone rearrangement.

The CHO cells were exposed in the test system for 1 hour, then washed and cuitured for an additional 20-30 hours, depending on the assay to be used. The total number of mutant colonies were determined and the mutation frequency was calculated. Chromosone aberrations were scored using 100 metaphases per dose and SCE per cell were calculated.

The cytotoxicity data indicate that micromolar amounts of $H D$ are highly toxic to cells in tissue culture. Average and induced aberration frequencies increased in a dose-dependent manner over a dose range of 0.5 to $1.0 \mu \mathrm{M}$. Likewise, Ho induced SCE increased in dose-dependent fashion in the dose 
range of 0.0625 to $0.25 \mu \mathrm{M}$. Mutation induction at the HGPRT locus was sporadic, but the majority of the exposures resulted in mutation frequencies which were 1.2 to 4.3 fold greater than spontaneous frequencies.

This report describes investigations of the in vitro genetic toxicology of sulfur mustard using the CHO cell line. Micromolar exposures of HD in vitro are highly toxic and results in marked chromosome damage and rearrangement. It appears that $H D$ is also mutagenic at the MGPRT locus. 
Page

FOREWORO ........................... 1

EXECUTIVE SUMMARY. ..................... 3

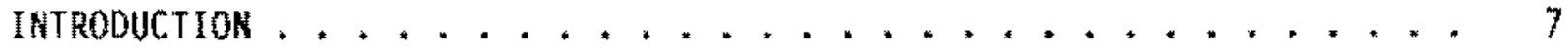

MATERIALS AND METHODS. . ................. 13

Sulfur Mustard. . . . . . . . . ........ 13

Sample Preparation and Analysis ............... 13

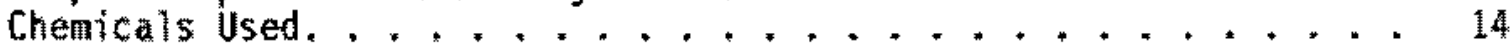

Cell Culture Media. . . . . .......... 16

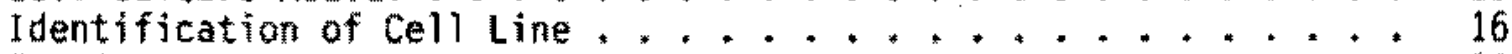

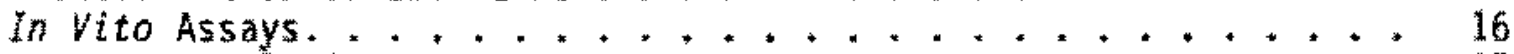

Mutation Analysis ...................... 17

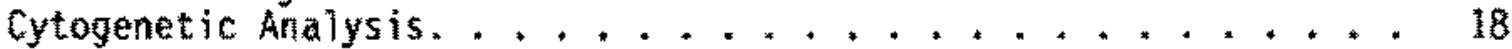

Statistical Analysis................... 18

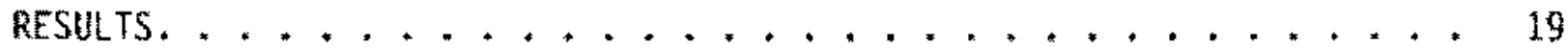

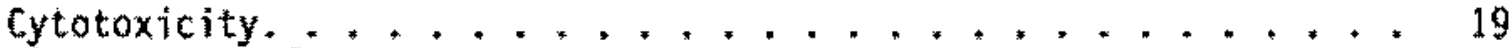

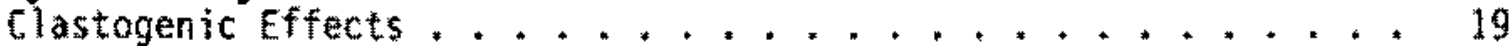

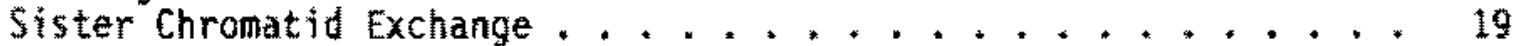

Mutation Frequency. ..................... 24

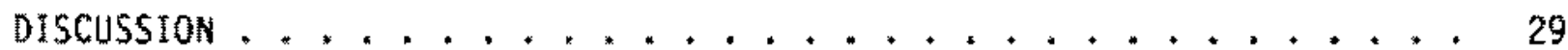

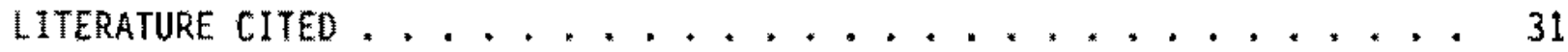

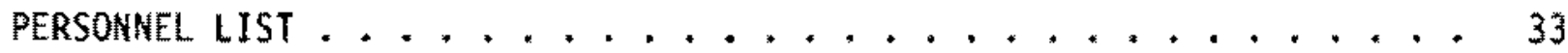

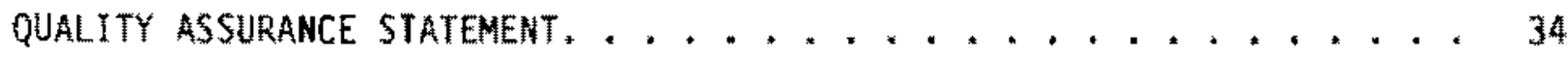

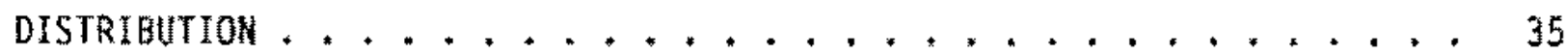

\section{LIST OF FIGURES}

Figure

Page

1 Fraction of cells surviving DH treatment.........20

2 Fraction of cells surviving HD treatment in the presence of $59 . \ldots \ldots \ldots 21$

3 SCE per metaphase after HD treatment without $5-9, \ldots . .24$

4 SCE per metaphase after HD treatment in the presence of $\$ 9.25$

5 Expression time for mutant induction in $\mathrm{CHO}$ cells..... 27

6 Increase in cell survival with time after treatment with

$5 \mathrm{mM}$ EMS and $1.8 \mu \mathrm{M} \mathrm{HD} \ldots \ldots . \ldots 28$ 


\section{LIST OF TABLES}

Table

Page

1 Relevant Chemical and Physical Properties of Sulfur Mustard, Bis (2-chloroethyl) Sulfide. ............ 8

2 Comparison of Theoretical and Analytical Concentrations of Ho in Ethanol Dosing Solutions . . . . . . . . . . 15

3 HD Induced chromosome Abberations in CHO Cells, ....... 22

4 HO Induced Sister Chromatid Exchange in CHO Cell....... 23

5 HD Induced Mutations at the HGPRT Locus in CHO Cell with or without $59 . \ldots .+\ldots$

H0 Induced Mutations at HGPRT Locus . . . . . . . . . 28 
INTRODUCTION

Chemical warfare agents present an obvious risk to individuals suffering acute exposures and may also present certain long-term environmental or occupational health hazards for workers. These materials are used in a number of research laboratories, stored in depot sites throughout the country and occasionally transported to distant sites. In addition, stockpiles of agents are scheduled for destruction by the U.S. Army in the future, creating an additional potential for environmental and occupational exposure. Although considerable information is known concerning the acute effects of these agents, little information is available on the long-term hazards of these materials including their carcinogenicity, teratogenicity and mutagenicity, especially in mamalian systems. It is therefore necessary that potentially toxic and mutagenic chemicals be identified and that a data base be established for the development of hazard evaluations and occupational health standards for these chemicals.

The two general categories of vesicants are typified by lewisite [dichloro(2-chlorovinyl)arsine] and sulfur mustard (HD) [bis(2-chloroethyl) sulfide] (Cassarett and Doul1, 1986). Contact with these chemicals produces severe skin burns. Recently, a renewed interest in these chemicals was generated by the release of a United Nations report that contained substantial evidence that Iraq was manufacturing and using these agents as chemical warfare agents (Marsha11, 1984).

The mustard compounds (both sulfur and $n$ itrogen) are biochemically related to a group of cytotoxic alkylating agents, including the ethylenimines, sulfonic esters, epoxides and n-aikyl-n-nitroso compounds (Wheeler, 1962). These chemicals react rapidly with certain functional groups of proteins $\left(0 \mathrm{H}, \mathrm{NH}_{2}\right.$, and $5 H$ ) to alter their metabolic activity. In aqueous solutions, both sulfur and nitrogen mustard hydrolyze to form cyclic sulfonium or immuiun forms, respectively, which, in turn, will react with nucleophilic sites. The sulfur mustard reaction proceeds more rapidly to the reaction with nucleophiles than does nitrogen mustard and is independent of the concentration of nucleophiles present (Fox and Scott, 1980). The cytotoxic, mutagenic, and carcinogenic 
properties of mustard compounds have been studied extensively (Fox and Scott, 1980), but most of these data relate to nitrogen mustard because sulfur mustard is a more toxic and chemically reactive vesicant.

Relevant chemical and physical properties of sulfur mustard are sumarized in Table 1. In aqueous solutions, sulfur mustard rapidy hydrolyses to form a cyclic sulfonium salt, $\beta$-chloroethyl-ethylenesulfonium chloride. This salt reacts with water to form $\beta$-chloroethyl- $\beta$-hydroxyethyl sulfide and hydrochloric acid. Subsequent hydrolysis of the sulfide, presumably through the intemediation of a second sulfonium salt, forms thiodiglycol (Anslow et al., 1948). These workers have investigated the toxicity of these derivatives of sulfur mustard and a number of other intermediates isolated from hydrolysates of sulfur mustard. They found that two of the derivatives, $\beta$-chloroethyl$\beta$-hydroxyethyl sulfide and thiodiglycol, were relatively nontoxic.

TABLE 1. Relevant Chemical and Physical Properties of Sulfur Mustard, Bis (2-Chloroethyl) Sulfidea.

\section{CAS}

RETCS:

Structural fomula:

Molecular weight:

Density at $25^{\circ} \mathrm{C}$ :

State:

Vapor pressure at $20^{\circ} \mathrm{C}$ :

Decomposition temperature:

Solubility in water at $25^{\circ} \mathrm{C}$ :

Hydrolys is

Rate (T1/2 at $\left.25^{\circ} \mathrm{C}, \mathrm{pH}^{7}\right):$

Products:

Army Abbreviation
$505-60-2$

w00900000

C) $-\mathrm{CH}_{2}-\mathrm{CH} 2-\mathrm{S}-\mathrm{Cl}-\mathrm{CH} 2-\mathrm{CH}_{2}$

159.19

1. $3 \mathrm{gIm}$

Coloriess, ally liquid

$0.072 \mathrm{~mm}$

$149-177^{\circ} \mathrm{C}$

$0.68 \mathrm{~g} / \mathrm{L}$

8.5 min

Thiodiglycol, chloride HD

aRosenblatt et al., 1975: Windholz, 1983. 
The carcinogenicity of nitrogen mustard is well docunented, but relatively little data are available for HD. Studies in mice have shown evidence of skin papillomas following subcutaneous HD treatment and lung tumors after intravenous injection or inhalation of HD (Fox and Scott, 1980). Studies conducted by the U.S. Army found little evidence of lesions in rabbits, quinea pigs and dogs after being exposed to HD vapor for up to 52 weeks, Treatment-related skin tumors were observed in rats exposed to $0.1 \mathrm{mg} / \mathrm{m}^{3} \mathrm{HD}$ vapor for as few as 12 weeks (McNamara et al. 1975). In an initiationpromotion study using a mouse-5kin model, HD was not found to be an active initiator of tumor development (Berenblum and Shubik, 1949). However. Japanese factory workers, who were involved in the production of chemical agents and who were potentially exposed to unknown quantities of various chemical agents including HD during World War II, show evidence of an increased incidence of respiratory and gastrointestinal tract cancers (Wada et al., 1968; Norman, 1975; Nishinoto et al., 1970; Manning et a1., 1981; Yamakido et a1., 1985).

The teratogenic potential of $H D$ was studied in rats exposed to two concentrations of inhaled HD $\left(0.001\right.$ and $\left.0.1 \mathrm{mg} / \mathrm{m}^{3}\right)$ during each of the 3 weeks of gestation or throughout the entire gestation period (McNarmara et al., 1975). No evidence of dose-related fetal mortality or gross abnomalities was noted. Teratology studies, following the segment II teratology protocol. were recently conducted in rats and rabbits by Hackett et al. (1987). Rats were exposed to $0.5-2.0 \mathrm{mg} / \mathrm{kg}$ HO by gastric intubation from 6 to 15 day of gestation (dg) and were killed on dg 20 . No evidence of a teratogenic response to HD was observed since fetal effects occurred only at doses exhibiting signs of maternal toxicity. Likewise, fetal development of rabbits exposed to $0.4-0.8 \mathrm{mg} / \mathrm{kg}$ Ho between 6 and $19 \mathrm{dg}$ was not affected even though maternal mortality was induced at the highest dose. These results suggest that $H D$ is not teratogenic in rats and rabbits since fetal effects were observed only at dose levels that induced frank maternal toxicity.

Mustard agents (mostly nitrogen) have been found to produce mutagenic affects in a wide variety of animal species and test systems. Reviews on the genetic toxicology of nitrogen mustard and HD have summarized the known effects of 
these agents in biological systems (Auerbach, 1949; Auerbach, 1976; Fox and Scott, 1980). Dominant lethal, sex-linked recessive and autosomal lethal, and visible mutations as well as major rearrangements and chromosomal aberrations have been reported in the fruit fly. The mutagentc potential of Ho was recently evaluated in the standard plate incorporation version and the preincubation modification the Salonella/microsomal (Ames) assay (stewart, 1987; Stewart et a $1 ., 1989$ ). Sulfur mustard induced point mutations in tester strain TA102 and frameshift mutations in TA97 but showed little or no mutagenicity against strains TA98 or TA100.

Relatively littie is know concerning the mutagenicity of $H D$ in mamalian species or test systems. Chronic inhalation exposure of nale rats to sulfur mustard $\left(0.1 \mathrm{mg} / \mathrm{m}^{3}\right)$ was reported to produce significant dominant lethal effects, but exposure of pregnant females to the same concentrations for a shorter time interval falled to induce fetal malfomations (Rozmiarek et al., 1973). McNamara et al. (1975) subsequently concluded from these same data that there were no differences between the control and experimental groups and no evidence of mutagenesis. It is difficult to resolve the apparent conflict between the conclusions of these two reports, but the fetal mortality values presented in the Kckanara report suggest at least a trend for a significant dominant lethal effect. Complete control data are missing from the report and statistical evaluation of the results is not presented, but percentage fetal death at week 12 were $4.12,4.24$, and 21.05 for controls, 0.001 and $0.1 \mathrm{mg} / \mathrm{m}^{3}$ exposure groups, respectively.

The bifunctional alkylating agent, HD, yields 7-alkylguanine as its principal alkylation product (Fox and Scott, 1980). Approximately 25 of these alkylations result in the fomation of the ONA cross-link, diguanine-7ethylmethylamine. DKA crossminks are implicated in the production of chromosomal aberrations and chromosomal rearrangements (Bodell et a1., 1985 ; Tokuda and Bodel1, 1987).

HD is a known clastogen which produces all of the types of chromatid aberrations commonly seen with ionizing radiation (Fox and Scott, 1900 ). Conversely, very few, if any, chromosome type aberrations have been observed 
after HD treatment. Some investigators feel that this observation suggests that only one strand of the DNA helix is affected by the cross-link (Fox and Scott, 1980). Infomation regarding the dose response relationships of to induced aberrations is ambiguous and a detailed analysis would require the use of synchronous cell populations and cell progression analysis. Nitrogen mustard ( $\left.\mathrm{HN}_{2}\right)$ induces chromosomal rearrangement (sister chromatid exchange) in mammalian chromosomes (Fox and Scott, 1980; Tokuda and Bodell, 1987).

HD has been reported to induce a linear increase in the mutation of $15178 Y$ cells as detemined by reversion from asparagine dependence (Capizzi et al.. 1973). The cytotoxicity, mutagenicity and the clastogenicity of HD using Chinese hamster ovary (CHO) cells were investigated in this study. 


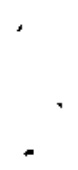


MATERIALS ANO METHODS

\section{Sil fur Mustard}

The HD used in these studies was $2,2^{\prime}$-dichlorodiethyl sulfide, also known as bis (2-choroetbyl) sulfide or distilled nustard (HD).

The Ho was supplied by the U.S. Army Medical Research Institute for Chemical Defense (USAMRICD), Chenical Surety/Safety office, Aberdeen Proving Ground, Edgewood Arsenal MO fron lot No. HD-U-4244-CTF-N-1, previously designated Lot No. ICO-HD-1. The material was prepared August 31,1981 and analyzed for purity September 4,1984 by Captain willian Beaudry and Linda Szafraniec (Research Directorate, Chenical Research and Development Center) by nuclear magnetic resonance. Purity, calculated on a weight basis, was 97.3 . There were two impurities with concentrations of $1.2 \%$ (assumed to be dithiane) and 1.5\% (identity unknown). Material from this lot has been proposed as the standard analytical reference for USAMRDC and USAMRDC has agreed to retain aliquots of this material to comply with the requirements of Good Laboratory Practices (GLP).

A shiphent of $25 \mathrm{ml}$ of $\mathrm{HD}$ (in two ampules) was delvered on March 7, 1985 by a team from the U,S. Army Technical Escort Unit. The ampules were inspected and found to be intact. Subsequently the HD was transferred from the ampules into 30-ml wheaton bottles, sealed and stored in secondary unbreakable containers in a refrigerated storage container at approximately $6^{\circ} \mathrm{C}$.

\section{Sample Preparation and Analys is}

Sulfur mustard is relatively insoluble $(0.68 \mathrm{~g} / \mathrm{L})$ and also is rapidy hydrolyzed in water, therefore absolute ethanol (EtOH) was employed as the diluent for this study. The HD solutions were prepared in advance and stored in a refrigerator at approximately $6^{\circ} \mathrm{C}$ overnight. The general procedure was to determine the amount of neat HD needed, based on the volumes to be prepared and the final concentrations desired. This volume was then renoved from the bottle of neat $\mathrm{HD}$ and thoroughly mixed into a known volume of 
ethanol. Aliquots of this intermediate concentration were then diluted further to give the final concentration needed for exposing the cells.

Methods were developed for the assay of HD in ethanol by gas chromatography, using a capillary column and flame-ionization detection. The procedure consisted of diluting $0.50 \mathrm{mi}$ of the HD-ethanol sample with $0.50 \mathrm{ml}$ of 18.7 $\mathrm{mg} / \mathrm{ml} \mathrm{2,4-dichlorotoluene} \mathrm{(DCT)} \mathrm{in} \mathrm{isooctane,} \mathrm{contained} \mathrm{in} \mathrm{a} 1.5-\mathrm{ml}$ atutomatic sampler vial with a Teflon-lined crimped-top cap. The DCT was used as an internal standard for the assay. A Hewlett-Packard $5840 \mathrm{~A}$ gas chromatograph and 7672 automatic sample changer were used with a capillary DB-5 column (J \& W Scientific, folsom, (A). The method can detect as low as $0.01 \mathrm{mg} / \mathrm{ml}$. The analytical results compared to theoretical values are presented in Table 2 for dose levels evaluated. Some samples, ranging in concentration from 0.00795 to $15.9 \mathrm{mg} / \mathrm{ml}$, were analyzed using this method on the day of their preparation and after they had been stored in a refrigerator at approximately $6^{\circ} \mathrm{C}$ for one day. The solutions at all concentrations appeared to be stable within $7 \%$ for at least one day. Since the precision of the analyses was also about this level, there appeared to be no evidence that the samples degraded during this period. All experiments were conducted within one day of preparing the test solutions.

\section{Chenicals Used}

The sulfur mustard used in this study was lot number HD-U-4244-CTF-N-1 and is described in an earlier section of this report. Dilutions of the agent were made up in absolute (punctilious) ethanol (EtOH - U.S. Industrial Chemical Co.). A new bottle of ethanol was used for each experiment. Ethyl methanesulfonate (eMs - sigma lot $\$ 95 \mathrm{~F}-0226$ ) was used as a positive control for mutation and sister chromatid exchange (SCE) studies. All EMS dilutions were made up in absolute ethanol. 6-aminocrysine (6-AC: Aldrich lot "092797) was used as a positive control for materials that required 59 activation. $6-A C$ was solubilized in dimethylsulfoxide (OMSO: American Type Culture, lot 129341). Metabolic activation was accomplished using Litton Bionetics rat liver $\$ 9$ preparation lot $\$ 07420$. The 6-thioguanine (6.T6: Sigma lot $\$ 15 \%$ * 4023), used as a selecting chemical in the HCPRT mutation assay, was made up 
Tabie 2. Comparison of Theoretical and Analytical Concentrations of HD in Ethanol Dosing Solutions.

\begin{tabular}{|c|c|c|c|c|c|}
\hline \multirow{2}{*}{$\begin{array}{c}\text { Data } \\
\text { Prepared } \\
7-29-86\end{array}$} & \multirow{2}{*}{$\begin{array}{c}\begin{array}{c}\text { Date } \\
\text { Analyzed }\end{array} \\
7-29-86\end{array}$} & \multirow{2}{*}{$\begin{array}{c}\text { Dose Level } \\
(\mu y) \\
100 \\
50 \\
10 \\
5 \\
1 \\
0.5 \\
0.1 \\
0.05\end{array}$} & \multicolumn{3}{|c|}{$\frac{\text { HD Concentration }(\mathrm{mg} / \mathrm{ml})}{\text { Analyzed* }}$} \\
\hline & & & $\begin{array}{l}15.9 \\
7.95 \\
1.59 \\
0.795 \\
0.159 \\
0.0795 \\
0.0159 \\
0.00795\end{array}$ & $\begin{array}{l}15.9 \\
1.52 \\
0.739 \\
0.144 \\
0.0703 \\
0.0135 \\
0.0063\end{array}$ & $\begin{array}{l}* 0 \\
* 0.035 \\
* 0.005 \\
* 0.005 \\
* 0.003 \\
* 0.0005 \\
* 0\end{array}$ \\
\hline $7-29-86$ & $7-30-86$ & $\begin{array}{c}100 \\
50 \\
10 \\
5 \\
1 \\
0.5 \\
0.1 \\
0.05\end{array}$ & $\begin{array}{l}15.9 \\
7.95 \\
1.59 \\
0.795 \\
0.159 \\
0.0795 \\
0.0159 \\
0.00795\end{array}$ & $\begin{array}{l}15.2 \\
7.81 \\
1.53 \\
0.734 \\
0.144 \\
0.0676 \\
0.0136 \\
0.0061\end{array}$ & $\begin{array}{l}=0.57 \\
* 0.02 \\
* 0.04 \\
* 0.003 \\
* 0.005 \\
* 0.0008 \\
* 0.0001 \\
* 0.0002\end{array}$ \\
\hline $8-5-86$ & $8-5-86$ & $\begin{array}{l}1 \\
0.5 \\
0.1 \\
0.05\end{array}$ & $\begin{array}{l}0.159 \\
0.0795 \\
0.0159 \\
0.00795\end{array}$ & $\begin{array}{l}0.159 \\
0.0648 \\
0.0140 \\
0.0057\end{array}$ & $\begin{array}{l} \pm 0 \\
\pm 0 \\
+0 \\
+0.0014\end{array}$ \\
\hline $12-8-86$ & $12-8-86$ & $\begin{array}{l}0.6 \\
0.4 \\
0.2 \\
0.15 \\
0.1 \\
0.05 \\
0.025 \\
0.012\end{array}$ & $\begin{array}{l}0.0954 \\
0.0636 \\
0.0318 \\
0.0238 \\
0.0159 \\
0.00795 \\
0.00397 \\
0.00198\end{array}$ & $\begin{array}{l}0.095 \\
0.073 \\
0.0325 \\
0.0570 \\
0.018 \\
0.0077 \\
0.0033 \\
0.00062\end{array}$ & $\begin{array}{l}* 0 \\
* 0.013 \\
* 0.0035 \\
* 0.0014\end{array}$ \\
\hline
\end{tabular}

* Mean * SD when duplicate samples were available. 
in sterile water as a $3 \mathrm{mM}$ stock solution and used at a final concentration in mediual of 30 w.

5'-Bromo-2-deoxyruidine (Brd Urd: Sigma lot 56 F0767). Hoechst dye (Sigma lot $25 \mathrm{~F}-3538$ ), and Giems stain (Gurr's improved 266 lot 172201 ) were used to differentiate sister chromatids. The Sorensen's buffer used in this technique was made up as $10 X$ solution $(A$ and $B$ stock). 5tock $A=9.079$

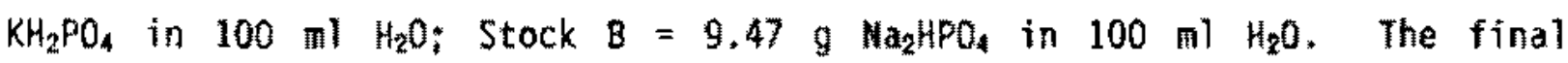
working solution was $10 \mathrm{ml} A$ and $10 \mathrm{ml} \mathrm{B}$ brought up to $100 \mathrm{~m} / \mathrm{s}$ total with $\mathrm{H}_{2} \mathrm{O}$ and the pH was adjusted to 6.8 .

\section{Cell Culture Media}

F12 medium supplemented with 5 fetal bovine serum (fbs) was used for routine cell culture. F12 medium - hypoxanthine (-HX) supplemented with 5: dialyzed fetal bovine serum (dfbs) was used for mutant selection.

\section{Identification of Cell Line}

The cells used in this study were designated $\mathrm{CHO} / \mathrm{C1B}$ which are a subcione of CHO used for mutation analys is (Jostes et al., 1980). These cells have been subsequently maintained in liquid nitrogen and cultured in F12 medium supplemented with $5 \%$ fetal bovine serum. Cell identification was routinely verified using chromosome analysis. Chromosone analysis included showing that the mean chromosome number was 21 and that the karyotype was consistent with cHo cells.

\section{In Vitro Assays}

One mutation assay and two cytogenetic assays were used in this study. The mutation assay utilized the hypoxanthine-guanine phosphoribosyl transferase (HGPRT) locus (6-thioguanine resistance). The two cytogenetic analyses were chromosomal aberration analys is (a measurement of chromosome danage) and SCE (a measurement of chromosome rearrangement). The experimental design for each was as described below. 


\section{Mutation Analys is}

In addition to the test compound, the CHO/HGPRT mutation assay contained the following elements; a positive control (EMS); a promutagen (6-AC) which required metabolic activation and solvent control (EtOH) which served as a negative control. Three concentrations of the test compound were assayed in replicate or triplicate. CHO cells were treated in $75 \mathrm{~cm}^{2}$ tissue culture flasks. Cells $\left(0.5-1.0 \times 10^{6}\right.$ per flask) plated into $10 \mathrm{ml} F 12$ medium with 5 total calf serum (fcs) and were incubated for 15-24 hours before exposure. The test compound was diluted in EtOH and a standard volume (50 1) was added to $10 \mathrm{ml}$ of $\mathrm{F} 12$ medium minus serum for cell exposure. Directacting mutagens were added to $10 \mathrm{ml}$ of $\mathrm{F} 12$ medium - fbs and incubated at $37^{\circ} \mathrm{C}$ for 1 hours $=5$ min.

Rat liver microsomes (\$9) were used in some experiments to activate promutagens. In this case the $\$ 9$ and associated cofactors were added to the medium just before treatment.

After treatment cultures were washed 3 times with saline $G$ and fresh $F 12+5 \%$ fbs was added to the cultures. The cells were then incubated for an additional 20-30 hours before trypsinization to alleviate possible trypsin effects. After trypsinization the cells were plated for initial survival (day 1) and for phenotypic expression (6-10 days). At the end of the expression period the cells were trypsinized and replated into $\mathrm{Fl2}+\mathrm{Hx}+5 \%$ dfbs for determination of plating efficiency and $5 \times 10^{4}$ cells/well were plated into 3, 6-well plates containing F12 - Hx, 30 yM 6-T6 and 5\% dfbs for selection of mutant colonies.

After colony formation the plates were fixed, stained, and counted. The total number of nutant colonies was determined at each treatment, as well as the plating efficiency. The mutation frequency was then calculated by dividing the total number of mutant colonies by the cells plated into 6-TG corrected for plating efficiency. 
Cytogenet ic Analys is

Treatment procedures were as described previously for the mutation assay. After treatment the cells were cultured for at least 24 hours in F12 medium supplemented with 5 bbs for aberration analysis, If the chromosomes were to be scored for SCE, $10 \mu \mathrm{M}$ BrdUrd was present in the medium after treatment. After approximately 24 hours colcemid was added at a final concentration of $0.08 \mu \mathrm{g} / \mathrm{ml}$. Metaphase cells were collected by the "shake" method and the suspended cells were centrifuged, swelled, fixed and burst onto microscope 5lides. Cells were prepared for aberration analysis by staining in 5: Giemsa. Chromosomes were prepared for SCE analysis by a modification of the methodology of Perry and Wolff (1974).

\section{Statistical Analysis}

Chromosone aberrations were scored using 100 metaphases per dose. In aberration studies each cell was evaluated as an individual treatment and means and standard errors are calculated within each experiment. Standard error is used because of the high number of naught values in each treatment and the poisson nature of aberration distribution. The standard error was determined by the formula: square root of the mean number of aberrations divided by the square root of the number of metaphases evaluated (Renington, 1970).

SCE were scored and the data is expressed as SCE/cell. Analysis of 30 metaphases/treatment was made and significant differences were determined using the more conventional standard deviations. 


\section{RESULTS}

\section{Cytotoxicity}

Figure 1 presents the CHO cell survival response (day 1) for 1 hour HD exposures as determined by colony formation in two experiments. Due to the high toxicity in Experiment $A$, further evaluation could not be performed. Using the data from experiment $B$ a $D_{37}$ of approximately $0.5 \mu \mathrm{M} H D$ and an extrapolation number of 4 was derived. When the cells were exposed in the presence of $\$ 9$ microsomal fractions, the survival was enhanced suggesting that the 59 itself interferes with HD toxicity (Figure 2).

\section{Clastogenic Effects}

A preliminary experiment indicated that $0.5 \mu \mathrm{M}$ HD induced an average of 0.22 $\neq 0.05$ aberrations per metaphase. This compared with a control value of 0.02 * 0.01 aberrations per metaphase and represents an induced frequency that is approximately 10 times the spontaneous value. Cell survival at this HD concentration was approximately $75 \%$ of the control value.

A dose range of 0.5 to $1.0 \mu \mathrm{M}$ was selected for further investigation. Table 3 presents dose response data from two experiments. In both experiments the average and induced aberration frequencies increased in a dose dependent manner. When cells were exposed to HD in the presence of $S 9$ (experiment $B$ ) a flat response was obtained. Because of this result and a similar inhibition of cytotoxicity (Figure 2) we did not include $S 9$ in experiment C. Although the absolute number of aberrations was higher in experiment $C$, the trend with increasing dose was similar in both experiments. In both experiments the standard errors of the lowest dose investigated $(0.5 \mu \mathrm{M} H \mathrm{HD})$ indicate that the induced aberration response is significantly greater $(P<0.05)$ than the control values.

\section{Sister Chromatid Exchange}

Table 4 presents data which shows that HD induces SCE in a dose dependent manner and at much lower concentrations than that required for aberration induction. Figure 3 presents data from experiment $B$ which illustrates the 


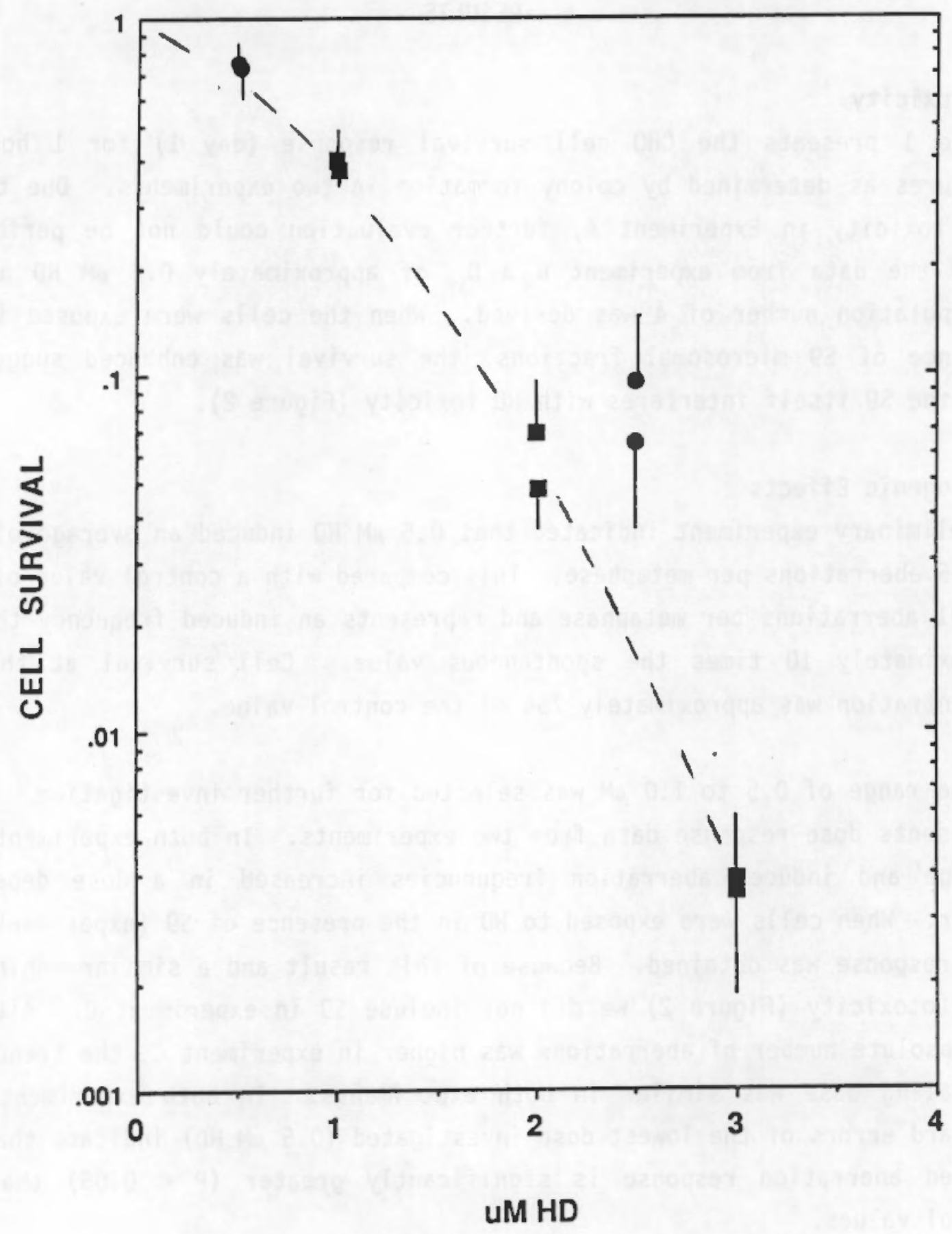

Figure 1. Fraction of cells surviving HD treatment (day 1). Circles are from experiment $A$ and squares are from experiment $B$. The line was drawn by eye to the data from experiment B. 


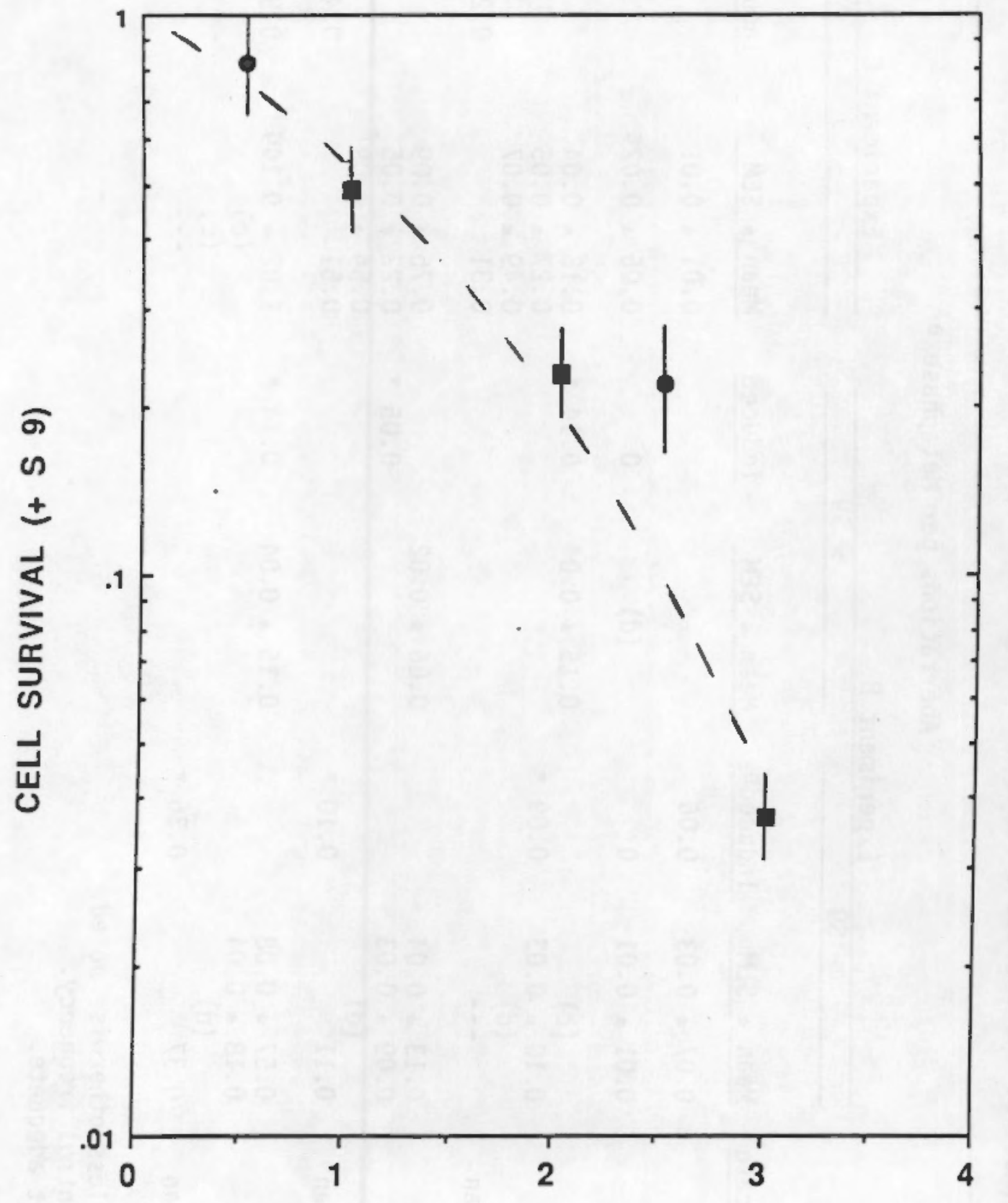

UM HD

Figure 2. Fraction of cells surviving HD treatment in the presence of $S 9$ (day 1). Circles are experiment $A$ and squares are experiment $B$. The line was drawn by eye to the data from experiment $B$. Note the increase in survival compared to that without 59 (Figure 1). 
TABLE 3. HO Induced Chromosome Aberrations in CHO Cells

Aberrations per Metaphase a

Experiment B

\section{$-\$ 9$}

$-\mathrm{Sxperiment} B$
+

Treatment

EMS Control (5 mM)

Control (EtOH)

$0.50 \mu \mathrm{M} \mathrm{HD}$

N

$0.75 \mu \mathrm{M} \mathrm{HD}$

$1.00 \mu \mathrm{M} \mathrm{HD}$

$$
\begin{aligned}
& \frac{\text { Mean }}{0.07}=\frac{\text { SEM }}{0.03} \quad \frac{\text { Inducedb }^{b}}{0.06} \\
& 0.01 \pm 0.01 \\
& 0
\end{aligned}
$$

$$
\text { (c) }
$$

$0.10 \neq 0.03$

(d)

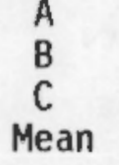

$--$

$$
\begin{aligned}
& \text { A } \\
& \text { B } \\
& \text { C }
\end{aligned}
$$$$
\text { Mean }
$$

$$
\begin{aligned}
& 0.13 * 0.04 \\
& 0.09 * 0.03 \\
& 0.11
\end{aligned}
$$$$
\begin{array}{ll}
\text { A } & 0.57 \neq 0.08 \\
\text { B } & 0.18 \neq 0.04 \\
\text { C } & \text { (d) } \\
\text { Mean } & 0.37
\end{array}
$$

$0.09 \star$

Mean $\neq$ SEM

Induced

$$
\begin{aligned}
& \text { Mean } \pm \text { SEM } \\
& 0.01 \pm 0.01 \\
& 0.06 \pm 0.02 \mathrm{e} \\
& 0.18 \pm 0.04 \\
& 0.27 \pm 0.05 \\
& 0.49 \pm 0.07 \\
& 0.31
\end{aligned}
$$

(d)

0

$$
0.15 * 0.04
$$

0.14 *

$0.76 * 0.09$

$0.22 \neq 0.05$

$0.54 \neq 0.79 f$

0.51

0.10 *

$0.15 * 0.04$

0.14 *

0.36 *
$1.02 * 0.149$

(c)
0.45 *

Induced

0.96 *

\footnotetext{
a 100 metaphases scored unless otherwise noted.

b Average HD value less control frequency.

c Chromosome morphology not adequate.

d Not done.

e Unusually high.

f 63 metaphases scored.

g 53 metaphases scored.

* Significantly different from background $(P<0.05)$.
} 
TABLE 4. HD Induced Sister Chromatid Exchange in CHO Cells

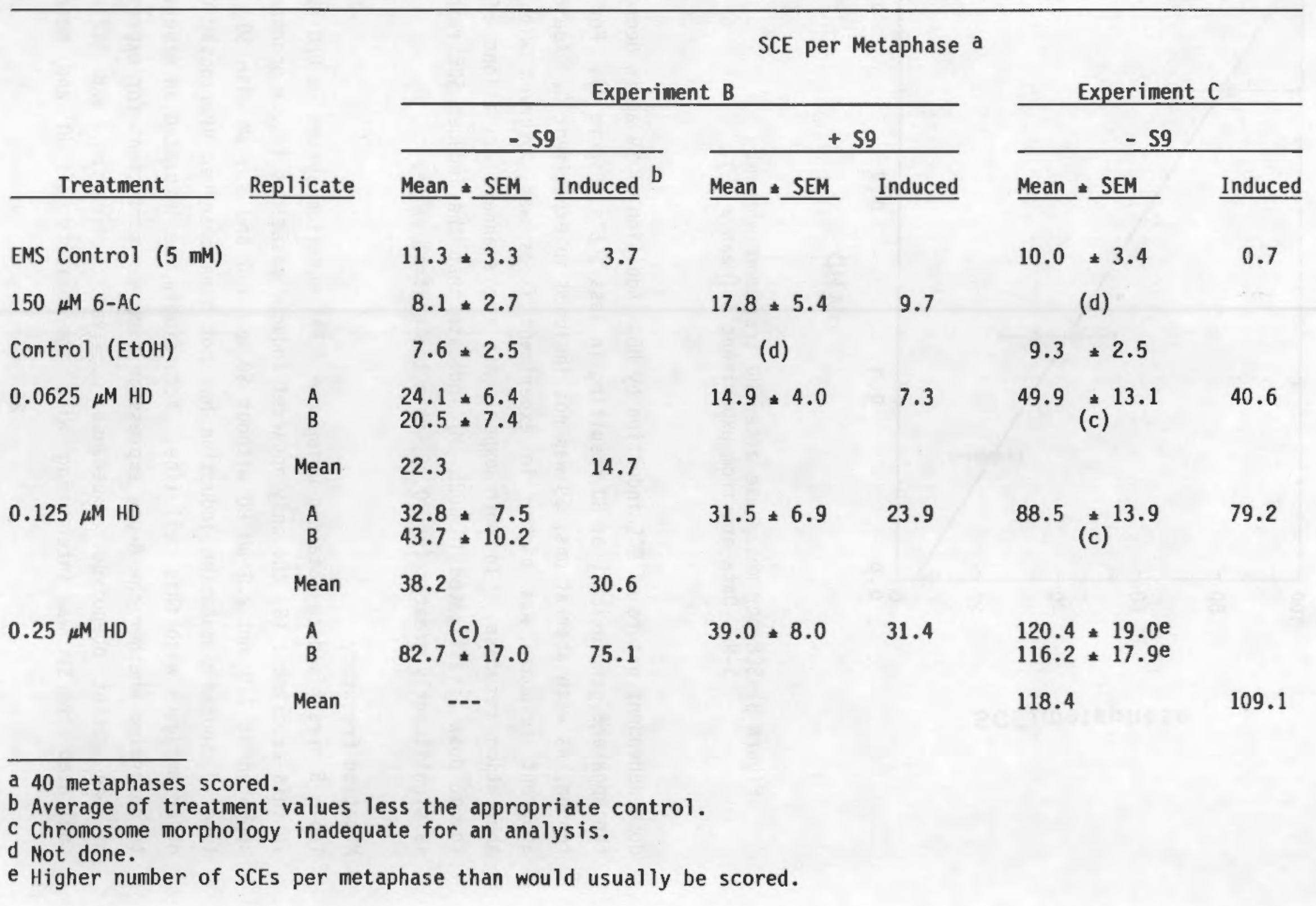




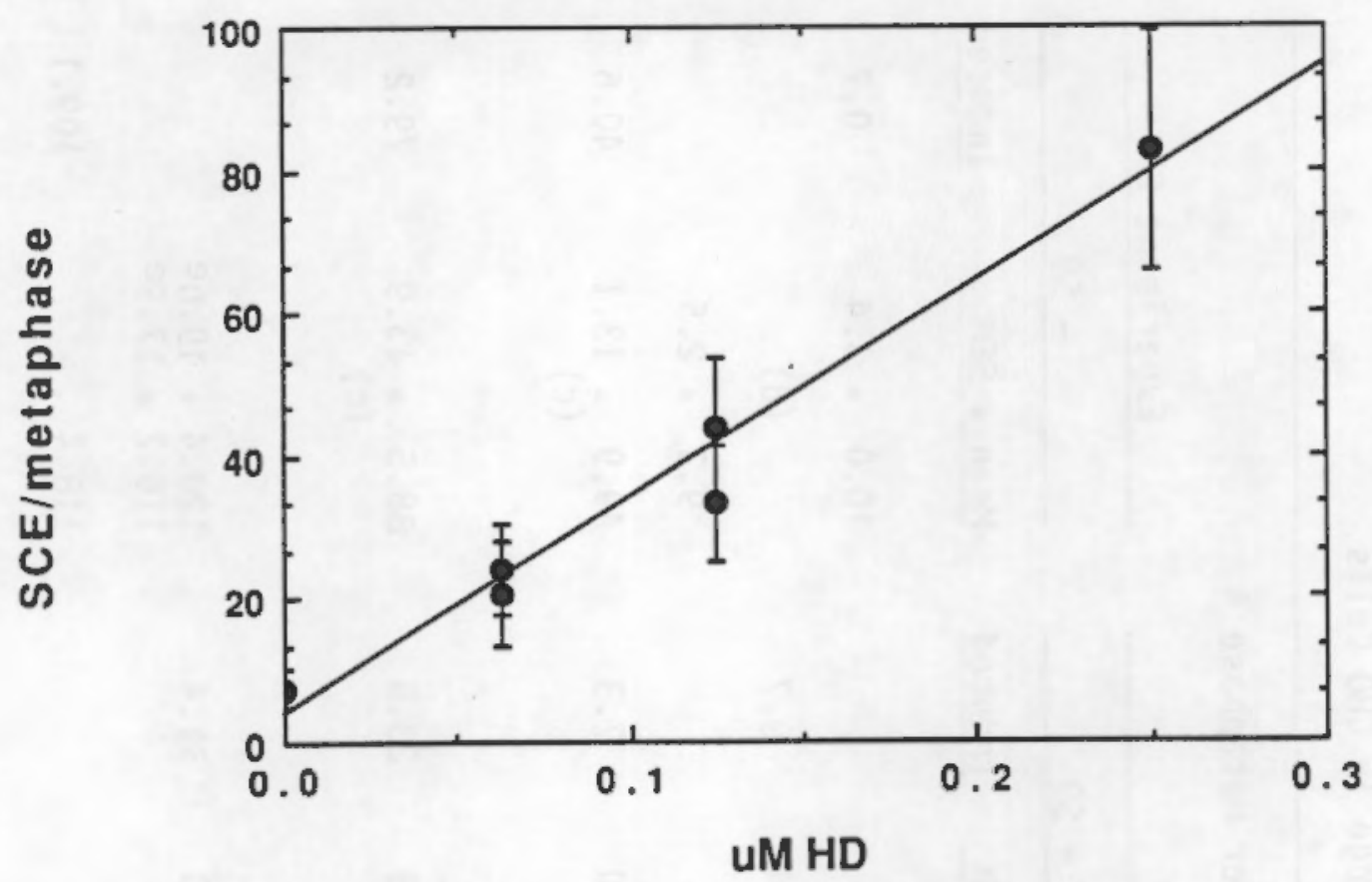

Figure 3. SCE per metaphase after HD treatment without $S-9$. Data are from experiment $B($ Mean $* S E)$.

dose dependent nature of SCE induction by HO. Addition of S9 again decreased the apparent genotoxicity of HD resulting in less SCE's (Figure 4). For this reason, as with aberrations, $S 9$ was not included in experiment C. Again the apparent response was higher in experiment $C$ as was observed with the aberration response. In both experiments the standard deviations of the lowest dose investigated $(0.0625 \mu \dot{M})$ indicate that the induced SCE response is significantly greater $(P<0.05)$ than the control values.

\section{Mutation Frequency}

Table 5 presents data obtained using the HGPRT mutation system in CHO cells. In this experiment (B) the only apparent induced mutations (above spontaneous) appeared at 1.0 and $2.0 \mu \mathrm{M} H D$ without $\mathrm{S} 9$ and 1.0 and $3.0 \mu \mathrm{M}$ with $\mathrm{Sg}$. This type of sporadic mutation induction has not been observed previously using other mutagens with this cell line. Accordingly, we initiated an experiment to determine whether the 8-day expression time was sufficient for expression of the mutant phenotype. Because survival, aberration, and SCE data indicated the $S 9$ was interfering with the toxicity of HD and because 


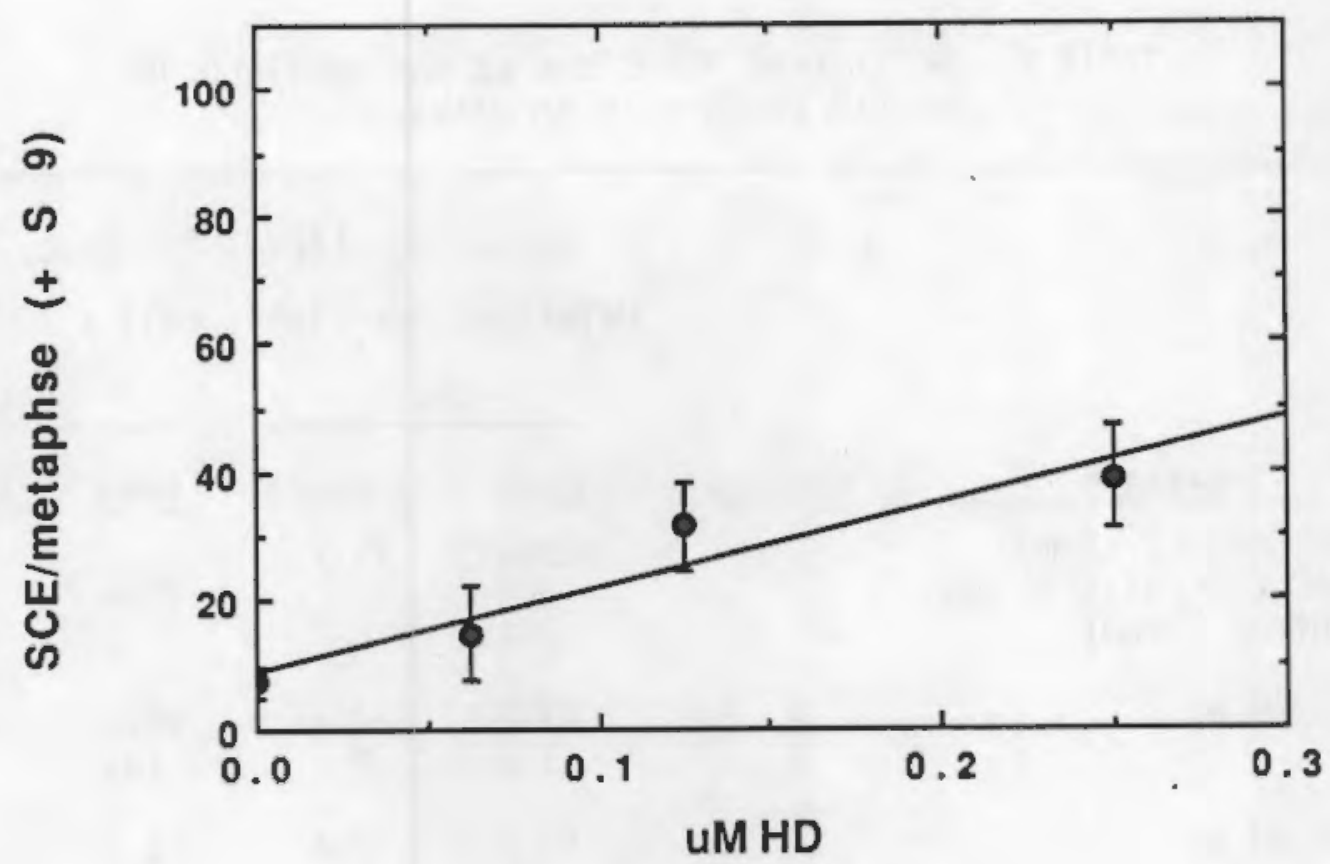

Figure 4. SCE per metaphase after HD treatment in the presence of S9. Note the reduction in SCEs induced when SS is present.

alkylating agents alkylate the DNA without metabolic activation, we investigated the expression of the mutant phenotype without $\$ 9$ activation.

Figure 5 presents the expression of HGPRT mutations with time after treatment with either $5 \mathrm{mM}$ EMS or $1.8 \mu \mathrm{M}$ HD, a concentration which would be expected to give an initial survival of approximately $10 \%$. Two serum lots, one dialyzed, were used in the expression time experiment. As can be seen from Figure 5, the maximal mutation frequency is attained with both agents after 5 days and the frequencies are essentially on a plateau when cells are replated into the selecting agent, 6-TG, between 5 and 13 days. The average frequency on the plateau is $49.5 \times 10^{-6}$ for HD treatment vs $.187 .0 \times 10^{-6}$ mutants per viable cell for EMS treatment. The lack of any spontaneous mutants before day 5 may in part reflect the low survival seen on day 0 and 3 (Figure 6) after HD treatment. The fact that the HO frequencies are on a plateau by day 5 , indicates that the recovery from cytotoxicity is only one factor in the 
TABLE 5. HD Induced Mutations at the HGPRT Locus in CHO Cells with or without S9

\begin{tabular}{|c|c|c|c|c|c|}
\hline \multirow[b]{3}{*}{ Treatment } & \multirow[b]{3}{*}{ Replicate } & \multicolumn{4}{|c|}{ Experiment B } \\
\hline & & \multicolumn{4}{|c|}{$\begin{array}{l}\text { Mutations per viable cell } \times 10^{-6} \\
-\$ 9 \\
\end{array}$} \\
\hline & & Mean & Induced & Mean & Induced \\
\hline $\begin{array}{l}\text { EMS Control }(1 \mathrm{mM}) \\
6-\mathrm{AC} \text { Control }(150 \mu \mathrm{M}) \\
\text { Control (EtOH) }\end{array}$ & & $\begin{array}{r}28.3 \\
6.4 \\
7.1\end{array}$ & $\begin{array}{c}21.2 \\
0\end{array}$ & 32.4 & 25.3 \\
\hline $1.0 \mu \mathrm{M} \mathrm{HD}$ & $\begin{array}{l}\mathrm{A} \\
\mathrm{B}\end{array}$ & $\begin{array}{r}21.2 \\
3.5\end{array}$ & $\begin{array}{c}14.1 \\
0\end{array}$ & $\begin{array}{r}28.3 \\
\text { (b) }\end{array}$ & 21.2 \\
\hline $2.0 \mu \mathrm{M} \mathrm{HD}$ & $\begin{array}{l}A \\
8\end{array}$ & $\begin{array}{r}16.5 \\
8.3\end{array}$ & $\begin{array}{l}9.4 \\
1.2\end{array}$ & $\begin{array}{l}1.2 \\
\text { (b) }\end{array}$ & 0 \\
\hline $3.0 \mu M H D$ & $\begin{array}{l}\text { A } \\
\text { B }\end{array}$ & $\begin{array}{l}0 \\
(a)\end{array}$ & 0 & $\begin{array}{r}46.0 \\
\text { (b) }\end{array}$ & 38.9 \\
\hline \multicolumn{6}{|c|}{$\begin{array}{l}\text { aAtypical plating efficiency } \\
\text { bNot done. }\end{array}$} \\
\hline
\end{tabular}

establishment of the mutant phenotype. In any case, it appears that the 8day expression time used in experiment $B$ (Table 5 ) is adequate for mutation analysis under these conditions. A third experiment was designed to investigate whether lower doses might result in a more uniform, dose related, induction of mutations by HD (Table 6). Again, one can see that the induction of HGPRT mutations does not increase with dose at these dose/levels, and futhermore, two of the treatments did not result in a recovery of mutations above the spontaneous value $(1.0 \mu \mathrm{M}$ replicate $\mathrm{C}$ and 1.8 $\mu \mathrm{M}$ replicate $\mathrm{A})$. In fact, the average induced values appeared to decrease with increasing dose, although not significantly. 


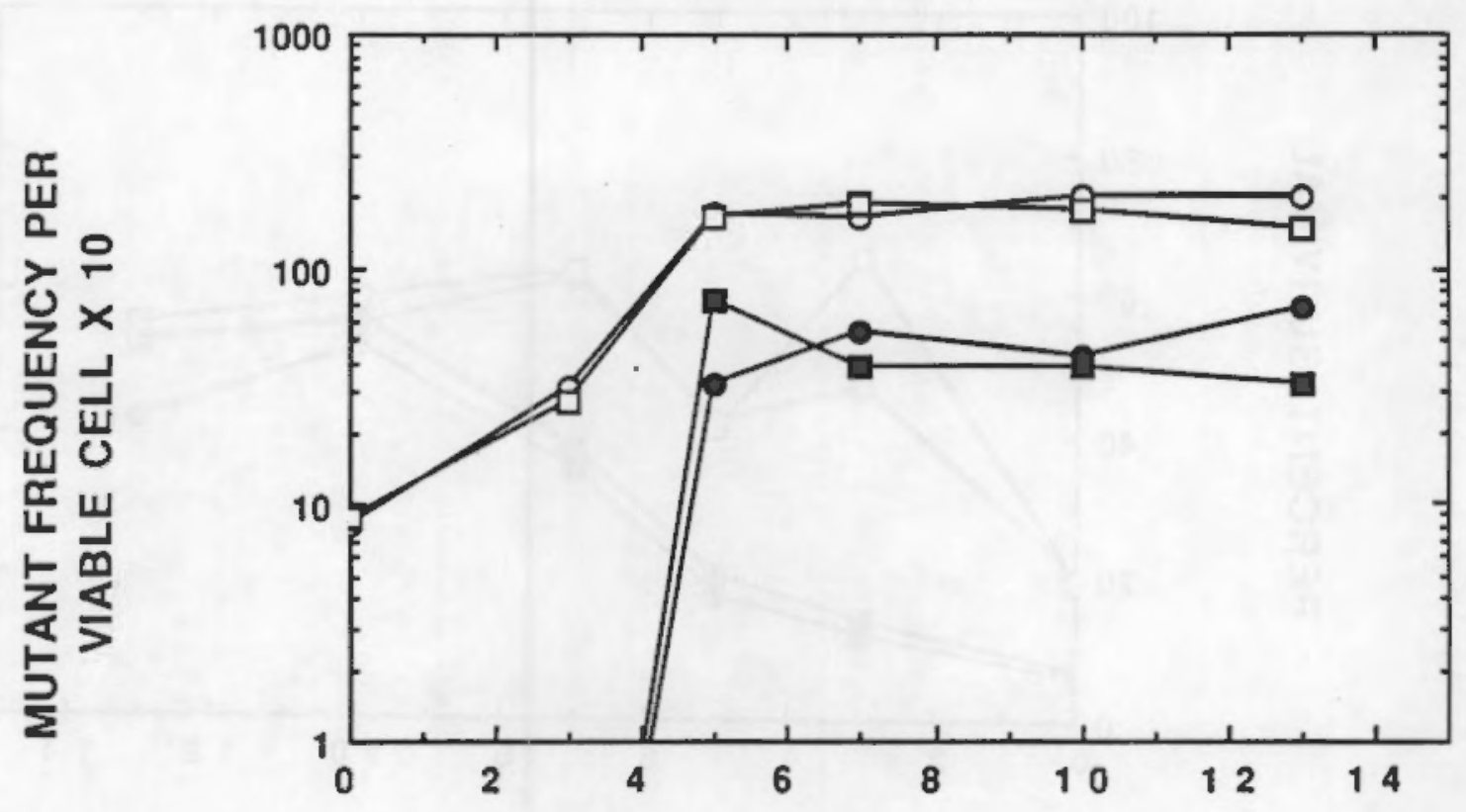

DAYS

Figure 5. Expression time for mutant induction in $\mathrm{CHO}$ cells. Circles are for $30 \mu \mathrm{M} 6-\mathrm{TG}$ in undialyzed serum and squares are the same conditions in dialyzed serum. Open data points represent mutants induced by 5 mM EMS treatment and closed data points represent mutants induced by $1.8 \mu \mathrm{M}$ HD treatment. The lack of spontaneous mutants on 0 and 4 days after HD treatment probably reflect the extremely low cell survival at these time points (see Figure 6). 


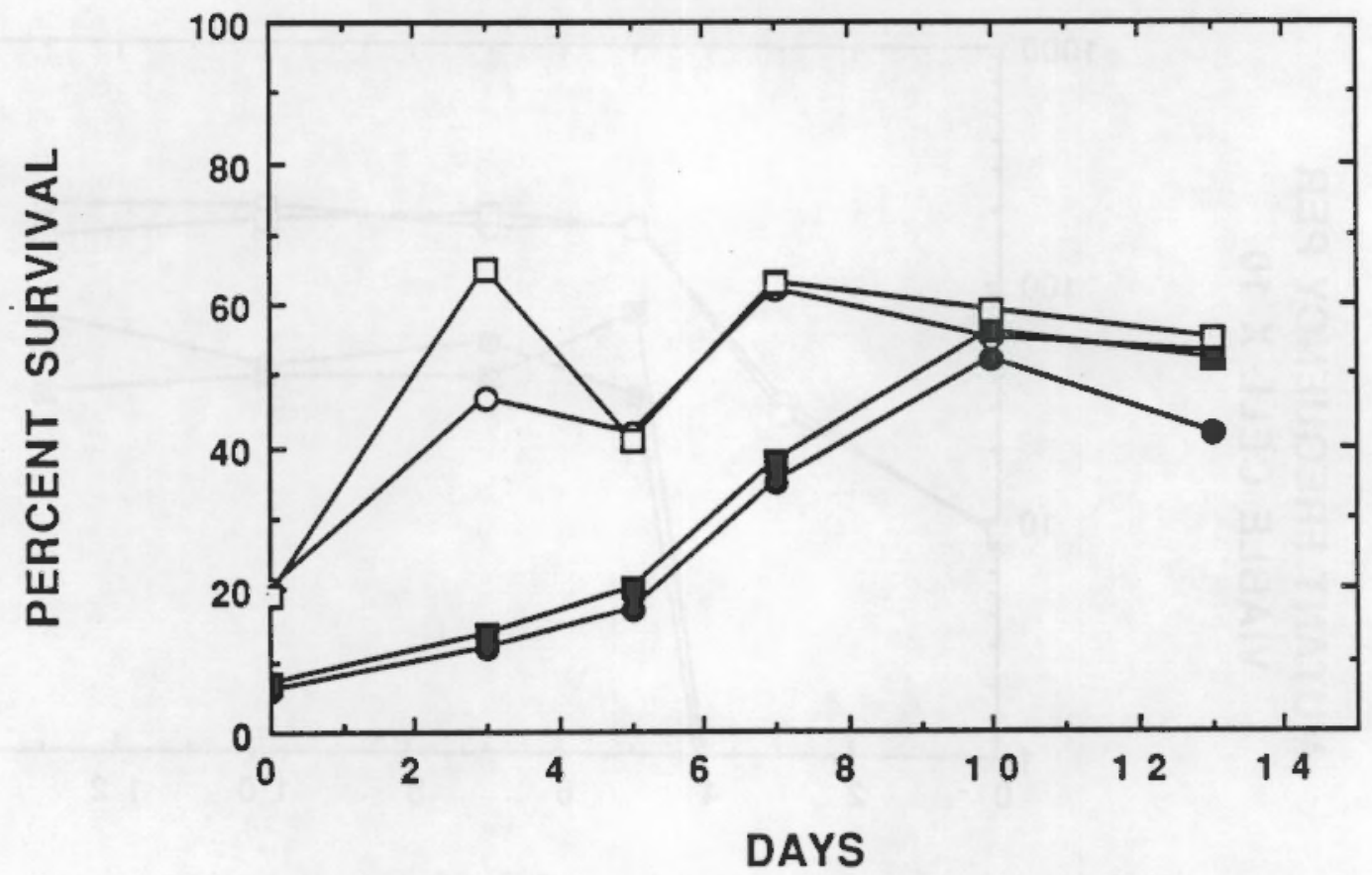

Figure 6. Increase in cell survival with time after treatment with $5 \mathrm{mM}$ EMS and $1.8 \mu \mathrm{M}$ HD. Open data points represent survival after $5 \mathrm{mM}$ EMS treatment and closed data points represent survival after $1.8 \mu \mathrm{M} H D$ treatment. Circles and squares are undialized and dialyzed serum respectively.

TABLE 6. HD Induced Mutations at the HGPRT Locus (-S9)

\begin{tabular}{|c|c|c|c|c|c|}
\hline \multirow[b]{3}{*}{ Treatment } & \multirow{3}{*}{ Replicate } & \multicolumn{4}{|c|}{ Experiment $D$} \\
\hline & & & \multicolumn{3}{|c|}{ Mutations per viable cell $\times 10^{-6}$} \\
\hline & & Frequency & Mean $\neq$ SE & Induced & $\begin{array}{l}\text { Induced } \\
\text { Average }\end{array}$ \\
\hline EMS Control $(5 \mathrm{mM}) \mathrm{a}$ & & 551.7 & & 530.7 & \\
\hline Control (EtOH) & & 21.0 & & & \\
\hline $1.0 \mu \mathrm{M} \mathrm{HD}$ & $\begin{array}{l}\text { A } \\
B \\
C\end{array}$ & $\begin{array}{l}49.4 \\
89.2 \\
18.1\end{array}$ & $52.2 \div 35.6$ & $\begin{array}{c}28.4 \\
68.2 \\
0\end{array}$ & 32.2 \\
\hline $1.4 \mu \mathrm{M} \mathrm{HD}$ & $\begin{array}{l}A \\
B \\
C\end{array}$ & $\begin{array}{l}68.6 \\
37.0 \\
26.8\end{array}$ & $44.1 \div 21.8$ & $\begin{array}{r}47.6 \\
16.0 \\
5.8\end{array}$ & 23.1 \\
\hline $1.8 \mu \mathrm{M} \mathrm{HD}$ & $\begin{array}{l}A \\
B \\
C\end{array}$ & $\begin{array}{l}20.2 \\
31.7 \\
28.5\end{array}$ & $26.8 \div 5.9$ & $\begin{array}{c}0 \\
10.7 \\
7.5\end{array}$ & 6.1 \\
\hline $\mathrm{Ne}$ & & & & & \\
\hline
\end{tabular}




\section{DISCUSSION}

The cytotoxicity data indicates that micromolar amounts of HD are highly toxic to cells in tissue culture. The one hour exposure in tissue culture medium (essentially water) should represent exposure to the entire toxic potential of HO, approximately 7 half-lives of the chemical in water. This toxicity is lowered slightly by the addition of $\$ 9$ microsomal fractions which may reflect moderation of the HD effect, possibly by supplying extracellular proteins which are cross-linked by the HD. If this is true one would expect that extracellular proteins in vivo would modify the toxicity of the HD exposure.

HD induces marked chromosanal effects at low micromolar concentrations. At

$1 \mathrm{MM}_{3}$ an HD exposure where approximately $40 \%$ of the cells survive, one sees aberrations in $37 \%$ (experiment $B$ ) or $96 \%$ (experiment $C$ ) of the metaphases. This is in general agreement with the assumption that aberrations are often a lethal event. The fact that a much higher frequency of aberrations was induced in experiment $B$ relative to experiment A suggests that dosing variables such as dilution schemes, and the short half-life of the HO $(8.5$ min), in the medium may render the determination of precise induced frequencies impractical. Interpretation of the dose response of induced aberrations is complicated by many factors, including cell progression and cell cycle sensitivity.

High levels of SCE, a measure of chromosonal rearrangement, which correlates well with mutagenicity, are induced by low nicromolar amaunts of HD. The induction is approximately linear in experiment $B$ as one would expect with cross-linking agents (Bodell et al., 1985; Tokuda and Bodell; 1987). The saturation at the highest dose in experiment $C$ probably reflects the fact that so many SCES were induced that some were not resolvable and therefore not scored. Tokuda and Bodell (1987) have shown that cross linking agents are extremely effective inducers of SCE. This is supported by the observation that $0.0625 \mu \mathrm{M} \mathrm{HD}$, the lowest dose used, which would not be expected to cause appreciable cell death, gave $3 x$ the spontaneous SCE frequency in experiment $B$ and $5 X$ the spontaneous frequency in experiment $C$. 
The sporadic nature of mutation induction at the HGPRT locus is unexpected. The expression time experiment indicates that adequate expression times were used in all experiments. Furthermore, it appears from this experiment that once the mutants are induced in a cell population they are stable in that population, at least from 5-13 days. It is unlikely that one exposure might induce a class of mutants that takes longer to express the phenotype than another. Furthermore, the doses used in experiment $D$ should not have killed the cells below the level of mutant induction. The fact that the induced frequencies decrease with increasing dose in experiment $D$ suggests that some sort of saturation phenomena is occurring, even at these low doses. Perhaps even lower doses are required to achieve a dose response with HD. In any case the majority of the exposures (71\%) resulted in mutation frequencies which were 1.2 to 4,3 fold greater than the spontaneous frequencies.

In sumary, we have investigated the in vitro genetic toxicology of sulfur mustard using the CHO cell line. Micronolar exposures of $H D$ in vitro are highly toxic and result in marked chromosone damage and rearrangement. It appears that HD is mutagenic at the HGPRT locus although the system may be saturated at the concentrations used. 


\section{LITERATURE CITED}

Anslow; W.P., D.A. Karnofsky, B.V. Jager, and H.W. Snith. 1948. The intravenous, subcutareous and cutaneous toxicity of bix (b-chloroethyl) sulfide (nustard gas) and of various derivatives. j. Phamacol. Exp. Therap. 93: 1-8.

Auerbach, C. 1949. Mutagenesis. Biological Reviews of the Cambridge Philosophical Soc. Cambridge Press. London.

Auerbach, C, 1976. Mutation Research: Problens, Results and Perspectives. Chapman and Hall, Londor.

Berenblum, I., and P. Shubik. 1949. An experimental study of the initiating stage of carcinogenesis, and remexamination of the somatic cell nutation theory of cancer. Brit. $\mathrm{J}$. Cancer 3 : $109-118$.

Bodel1, W.J., T. Aida, and J. Rasmussen. 1985. Comparison of sisterchromatid exchange induction caused by nitrosureas that alkylate and crosslink DNA. Mutat. Res. 149, 95-100.

Capizzil, R. L., H. W, J. Smith, R. Field, and R. Papimeister, 1973. A host. mediated assay for chenical mutagens using $15178 \mathrm{Y} / \mathrm{Asn}$ murine leukaemia. Mutat. Res. 21: 6 .

Cassarett, L. J., and J. Doull. 1986. Toxicology. The Basic Sclence of Poisons, 3rd Ed, MacMillan Publishers, New York, WY.

Fox, M, and D. Scott. 1980. The genetic toxicology of nitrogen and sulfur mustard. Mutat. Res, $75: 131-168$.

Hackett, P.L., R.L. Rommereim, F.G. Burton, R.L. Euschbom, and L.8. Sasser. 1987. Teratology studies on lewisite and sulfur mustard agents: Effects of sulfur mustard in rats and rabbits. AD A187495. U.S. Amy Medical Research and Development Command, Fort Detrick, Frederick, MD.

Jostes, R.F., K.M. Bushnell, and W.C. Dewey, 1980, X-ray induction of 8azaguanine-resistant mutants in synchronous chinese hamster ovary cells. Radiat. Res. 83: 146-161.

Manning, K.P., D.C.G. Skegg, P.M. Stelland, and R. Doll. 1981. Cancer of the larynx and other occupational hazards of mustard gas workers. Clin. otol aryngol $6: 165-170$.

Marshall, E. 1984. Iraq's chemical warfara: case proved. Science 224: $130-132$.

McNamara, B.P., E.J. Owens, M.K. Christensen, F.J. Vocci, D.F. Ford, and H. Rozimarek. 1975. Toxicological basis for controlling levels of mustard in the environment. EB-SP-74030. Edgewood Arsenal, Aberdeen Proving Ground, MD. 
Nishimato, $Y .$, B. Burrows, M. Miyanishi, S. Katsuta, T. Shigenobu, and L.J. Kettel. 1970. Chronic obstructlve lung disease in Japanese poison gas workers. Am. Rev, Respir. Dis. 102: 173-179.

Norman, J.E. 1975. Lung cancer mortality in World War I veterans with mustard-gas injury: 1919-1965. J. Nat1. Canc. Institute 54: 311-317.

Perry, $P_{*}$ and $S$. Wolff. 1974. New Giems method for the differential staining of sister chromatids. Nature (London), 251, 156-158.

Remington, R.D. 1970. Statistics With Application to the Blological and Health Sciences, Prentice Hall, Englewood Cliff, New Jersey.

Rosenblatt, D.H., T.A. Miller, J.C. Dacre, I. Muul, and D.R. Cogley (eds.). 1975. Problem definition of potential environmental pollutants. 11. Physical, chemical, toxicological and biological properties of 16 substances, AD A030428 In: U.S. Army Medical Bioengineering Research and Development Technical Report 7509. Fort Detrick, Frederick, MD.

Rozmiarek, H., R.L. Capizzi, B. Papimeister, W.H. Fuhrman, and W.W. Smith. 1973. Mutagenic activity in somatic and germ cells following chronic inhalation of sulphur nustard. Mutat. Res. 21: 13-14.

Stewart, D. L., E. J. Sass, L. K. Fritz, and L.B. Sasser. 1989. Toxicology Studies on Lewisite and Sulfur Mustard Agents: Mutagenicity Study of Sulfur Mustard in the Salomonella Histidine Reversion Test. U.\$. Army Medical Research and Development Command, Fort Detrick, Frederick, MO.

Stewart, 0. L. 1987. Mutagenicity study of sulfur mustard in the Salmonella histidine reversion test. Environ. Mutagen. 9: 103-104.

Sweet, D.V. 1987. Registery of toxic effects of chemical substances, Vol, 5. p. 1968. U.S. Government Printing Office, Washington, D.C.

Yokuda, K., and W. J. Bodell. 1987. Cytotoxicity and sister chromatid exchanges in $9 \mathrm{~L}$ cells treated with monofunctional and bifunctional nitrogen mutzards. Carcinogenes is $8: 1697-1701$.

Wada, S., Y. Nishimoto, M. Miyanishi, \$. Kambe, and R.W. Miller. 1968. Mustard gas as a cause of respiratory neoplasia in man. The Lancet 7753: $1161-1163$.

Wheeler, G.P. 1962. Studies related to the mechanism of action of cyctotoxic alkylating agents. Cancer Res. 22:651-688. Windholz, $\mathrm{M}_{*}$ (ed.). 1983.

Winthol2, M, 1983. The Merck Index, p. 904, Merck, Rahway, Mu.

Yamakido, M., and T. Shigenobu. 1985. The causes of death in the retired workers of Okuno-Jima poison gas factory. Jpn. J. Med. $34: 311-322$. 


\section{PERSONNEL LIST}

Function

Principal Investigator

Facility Manager

Solution Preparation and Analysis

Exposures

Laboratory Evaluations

Study Director

Study Dates
Name

R.F. Jostes, Jr.

M.T. Karagianes

D.R. Kalkwart

L.B. Sasser

C. Veverka, Jr.

R.F. Jostes, Jr.

C. Lindenmeir

R.F. Jostes, Jr. R.J. Rausch

L. B. Sasser

Intitiated: 29 July 1986

Completed: 15 April 1987

Data are property of the U.S. Amy and will be archlved under the amy's direction at approved facllities.
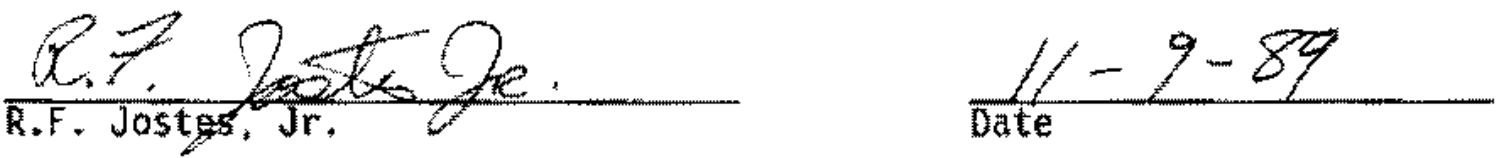


\title{
Genetic Toxicity of Sulfur Mustard (HD) in Chinese Hamster Ovary Cells
}

\author{
Quality Assurance Statement
}

Listed below are the phases and/or procedures described in this report which were reviewed by the Quality Assurance Unit specifically for this study and the dates the reviews were performed and findings reported to management. (All findings were reported to the study director or his designee at the time of the review.)

Phase/Procedure Reviewed

Dosing**

Replating for Mutation Evaluation Aberration \& SCE Staining

Replating for Mutation Evaluation Data

Final Report
Review Date

$12 / 9 / 86$

$12 / 10 / 86$

$12 / 15 / 86$

$4 / 23 / 87$

$9 / 6 \& 7 / 89$

$9 / 6,7 \& 10 / 30,31 / 89$
Date Findings Submitted in Writing to Study Director/Management

$4 / 7 / 87$

$4 / 7 / 87$

$4 / 7 / 87$

4/24/87

$11 / 7 / 89$

$11 / 7 / 89$

** Review of dosing was limited to the positive and solvent controls.

$\frac{c h 1 / 84}{\text { Quality Assurance Auditor }}$




\section{DFFSITE}

Commander (25)

U.5. Army Medical Research and Development Laboratory

Attn: SGRD-UBZ-RA

Fort Detrick

Frederick, MD 21701-5010

Commander (2)

U.S. Army Medical Research and Development Command

Attn: SGRO-PLE

Fort Detrick

Frederick, MD 21701-5012

Commander (2)

U. S. Army Medical Research Institute of Chemical Defense Attn: SGRD-UV-ZB

Aberdeen Proving Grounds, MD

\section{ONSLIE}

DOE Operations office

E.C. Norman/D.L. Sours

Pacific Northwest Laboratory

Publishing Coordination

Technical Report Files (5)

R.F. Jostes, Jr. (3)

L.B. Sasser (3)
Commander (3)

U.S. Army Medical Research and Development Command

Attn: SGRD-RMI-S

Fort Detrick

Frederick, MD 21701-5012

Chemical Effects Information Center (1)

Oak Ridge National Laboratory P.0. Box $X$

Oak Ridge, IN 37831 
